utgjør inflammatoriske hudsykdommer en dominerende del av den daglige praksis, og behandlingen er i de senere år blitt revolusjonert av nye, immunbaserte medikamenter, såkalte biologiske midler. Man får i denne utgivelsen dypere forståelse av de enkelte sykdommenes immunologi og hvilke muligheter og begrensninger som ligger i biologisk behandling, den vil derfor være nyttig som oppslagsverk for dermatologer som behandler slike pasienter.

Ingeborg Bachmann

Hudavdelingen

Haukeland universitetssykehus

\section{Hudsykdom etter organtransplantasjon}

Otley CC, Stasko T, red.

Skin disease in organ transplantation

364 s, tab, ill. New York, NY: Cambridge University Press, 2008. Pris USD 185 ISBN 978-0-521-87067-2

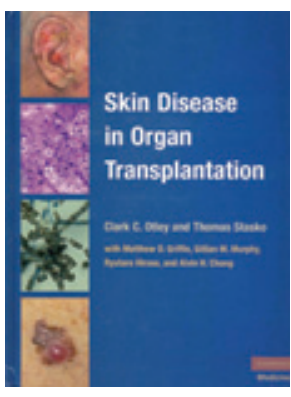

Organtransplantasjon er i dag veletablert behandling ved langkommet organsvikt, særlig nyresvikt og hjertesvikt. Stadig flere organtransplantasjoner og lengre overlevelsestid har ført til økt oppmerksomhet omkring langtidsbivirkninger av den immundempende behandlingen pasientene må bruke.

Organtransplanterte pasienter vil over tid utvikle en rekke hudkomplikasjoner. Viktigst er at de har en sterkt økt risiko for hudkreft, særlig plateepitelkarsinom - risikoen for kutant plateepitelkarsinom er over 60 ganger så høy som i en normalbefolkning i samme alder. Premaligne solare keratoser og basalcellekarsinomer er også langt hyppigere. Verrucae vulgaris (vorter) er svært vanlig og kan pga. antall, størrelse og lokalisasjon på fingre og føtter hemme daglige aktiviteter og livskvaliteten.

Forfatterne er medlemmer av International Transplant Skin Cancer Collaborative (ITSCC), et overveiende amerikansk og australsk nettverk av hudleger og andre med særlig interesse for hudsykdom etter organtransplantasjon, med bistand fra medlemmer av et tilsvarende nettverk i Europa - Skin Care in Organ-transplant Patients (SCOPE). Til sammen 44 forfattere tar i 53 kapitler for seg bl.a. generell transplantasjonsmedisin, immunologi, immunsuppresjon og kutane infeksjonssykdommer, benigne og inflammatoriske hudsykdommer, premaligne keratoser og ikke minst ulike former for hudkreft og behandlingen av slike hos organtransplanterte.

Hudsykdommer kan få et noe avvikende morfologisk uttrykk hos organtransplanterte, noe som fremheves flere ganger. De fleste kapitlene har en klinisk tilnærming, men leseren får også en bred og god oversikt over mulige mekanismer bak den akselererte epidermale karsinogenesen, der manglende reparasjon av solindusert DNA-skade som følge av vedvarende immunsuppresjon står sentralt. Kaposis sarkom, en sjelden kreftform også hos organtransplanterte, skyldes infeksjon og reaktivering av et herpesvirus (type 8). En mulig sammenheng mellom humant papillomvirus-infeksjon og kutant plateepitelkarsinom er fortsatt uavklart - her er fremstillingen nøktern og balansert. Flere av forfatterne etterlyser bedre informasjon, organisering og samarbeid mellom hudleger, plastikkirurger og transplantasjonsmiljøene. Kvaliteten på bidragene er gjennomgående høy og bruken av illustrasjoner svært god. En del overlapping mellom ulike kapitler er uunngåelige $i$ en utgivelse med så mange forfattere, men emnefordelingen virker fornuftig og redigeringen god.

Skin disease in organ transplantation bør finnes ved alle hudavdelinger og hudlegekontorer der organtransplanterte med hudsykdom behandles, og bør også være av interesse for indremedisinere som har ansvar for oppfølging av organtransplanterte pasienter.

\section{Petter Gjersvik}

Hudavdelingen

Rikshospitalet

\section{Fysisk aktivitet og type 2-diabetes - hva skjer på cellenivå?}

Hawley JA, Zierath JR.

\section{Physical activity and type 2 diabetes}

Therapeutic effects and mechanisms of action. 219 s, tab, ill. Leeds: Human Kinetics, 2008.

Pris GBP 44

ISBN 978-0-7360-6479-8

Ifølge redaktørene får man her oppdatert kunnskap om noen av mekanismene for hvordan fysisk inaktivitet bidrar til insulinresistens. Det er bidrag fra ledende forskere innen feltet. Man henvender seg til studenter og forskere innenfor basalfag og farmakologi så vel som til klinikere. Målet er at kunnskap fra biomedisinsk forskning i samspill med tiltak fra offentlige myndigheter - kan bidra til nye behandlingsmetoder for å begrense følgene av den globale epidemien av insulinresistens.

Det er fire deler.

Del 1 inneholder to kapitler om årsakene til insulinresistens og type 2-diabetes og om forekomst og konsekvenser av diabetesepidemien. En offensiv holdning til «krigen» mot type 2-diabetes gjennom primærprevensjon basert på treningsbiologi kommer tydelig frem.

I del 2 går man rett ned på celle- og molekylnivå og oppsummerer kunnskap om sammenhengen mellom metaboliske defekter og insulinresistens. I fem kapitler omtales fettsyreopptak og insulinresistens, lipidmetabolismen og konsekvenser for insulinsignaleringen, redusert metabolsk fleksibilitet ved insulinresistens i skjelettmuskulatur, sammenhengen mellom overordnet regulering av næringsinntak og fedme og diabetesrisiko og til slutt inflammasjonsindusert insulinresistens ved fedme.

Del 3 omhandler i fem kapitler forebygging av type 2-diabetes gjennom trening. Fortsatt er utgangspunktet det som skjer i cellene, som påvirkning av transkripsjonsfaktorer og mitokondrienes oksidative kapasitet, effekt av trening/fysisk aktivitet versus kalorirestriksjon, effekter av trening på kort og lang sikt og av styrketrening spesielt.

Også i del 4 legges det ifølge overskriften vekt på forebygging av type 2-diabetes, men omtalen begrenses i de tre kapitlene til nye molekylære angrepspunkter for behandling.

Alt dette forutsetter god kjennskap til biokjemiske prosesser på cellenivå, til signalveier og enzymer og transkripsjonsfaktorer. En rekke forkortelser blir brukt - uten at det alltid er enkelt å finne ut hva disse står for. Figurene er i svart-hvitt, og både disse og tabellene er ofte overlesset med informasjon. I kapittel 4 er det ikke samsvar mellom tabelltekst og figur $4.1 \mathrm{og} 4.2$. I de innledende kapitlene er det brukt litt gamle referanser om global diabetesforekomst.

Selv om mange av forfatterne har en stor vitenskapelig produksjon og formidler interessant kunnskap, savner jeg en mer helhetlig presentasjon av type 2-diabetes og hvordan sykdommen kan forebygges. Betacellenes betydning for type 2-diabetes omtales lite. Og selv om kunnskap fra basalmedisinsk forskning utvilsomt er viktig for å forstå hvordan sykdom oppstår og for eventuelt å finne nye terapeutiske muligheter for behandling, vil diabetes- og inaktivitetsepidemien også kreve kunnskap om samfunnsmessige strategier. Tittel og undertittel gjorde at jeg trodde jeg hadde nødvendige forutsetninger for å skrive denne anmeldelsen, men mye var for vanskelig for meg. Physical activity and type 2 diabetes har trolig liten relevans for klinikere uten god basalmedisinsk kunnskap og for myndighetene som skal utvikle og iverksette tiltak på befolkningsnivå for å begrense diabetesepidemien. Tittelen kan dermed være delvis villedende.

Anne Karen Jenum

Forskningssenteret

Aker universitetssykehus 